\title{
Efficacy of Electrolyzed Water to Inactivate Foodborne Pathogens on Fresh-Cut Apples
}

\author{
A. Graça and C. Nunes \\ ICAAM-Universidade do Algarve \\ FCT Ed 8. Campus de Gambelas \\ Faro \\ Portugal \\ M. Abadias and J. Usall \\ IRTA, Centre UdL-IRTA \\ XaRTA-Postharvest \\ 191 Rovira Roure Avenue \\ Lleida, Catalonia \\ Spain
}

\author{
C. Quintas \\ CIQA-Universidade do Algarve \\ ISE, Campus da Penha \\ Faro \\ Portugal \\ M. Salazar \\ CICAE. Instituto Universitário \\ D. Afonso III (INUAF) \\ Loulé \\ Portugal
}

Keywords: acidic electrolyzed water, chlorine, Escherichia coli, Listeria innocua, neutral electrolyzed water, Salmonella choleraesuis

\begin{abstract}
Chlorine is the most common disinfectant used in the fresh-cut industry but nowadays environmental and health risks have led to the need to find new sanitizers. Electrolyzed water (EW) appears to be a promising alternative. In this work, disinfection efficacy of acidic (AEW) and neutral (NEW) electrolyzed water in freshcut apple slices inoculated with Escherichia coli, Listeria innocua or Salmonella choleraesuis was studied. Apple slices were inoculated with a $10^{7} \mathrm{cfu} / \mathrm{ml}$ suspension of pathogens and treated with the sanitizer EW solutions, with $100 \mathrm{or} 50 \mathrm{ppm}$ of free chlorine solutions and with distilled water. Population reduction was determined $30 \mathrm{~min}$ after washings and untreated apple slices were used as control in all assays. AEW100 was the treatment with more effective bactericidal activity followed by NEW100 and AEW50. EW had higher or similar efficacy than chlorine treatments in all tested conditions.
\end{abstract}

\section{INTRODUCTION}

Fresh-cut produce is a rapidly rising sector of the horticultural industry because minimally processed fruits and vegetables offer many advantages to the final consumer. Fresh fruits and vegetables may contain a high contamination level after harvest, ranging between 3 and 7 log colony units depending on the season and type of produce (Ölmez and Krestzschmar, 2009). Therefore, fresh produce can be a vehicle for the transmission of bacterial, parasitic and viral pathogens that can cause human illnesses. Fresh fruit products have been associated with outbreaks of illness caused by E. coli $\mathrm{O} 157: \mathrm{H} 7$ and Salmonella spp. (del Rosario and Beuchat, 1995; Beuchat, 1996; Burnett and Beuchat, 2000). Moreover, several studies have shown that E. coli O157:H7, Salmonella spp. and Listeria monocytogenes can grow in fresh fruit tissues, such as in apples, (Beuchat, 1996; Janisiewicz et al., 1999; Leverentz et al., 2001; Park et al., 2001; Alegre et al., 2010; Oliveira et al., 2010).

Washing fresh-cut fruits with sanitizing solutions is the only step in the process where a reduction of microbial contamination can be obtained (Allende et al., 2009; Ölmez and Kretzschmar, 2009). Chlorine applied at concentrations ranging from 50 to $200 \mathrm{ppm}$ with a contact time of 1-2 min (Beuchat, 1998) is the most common sanitizing procedure used in the fresh-cut industry. However, there are some concerns about its efficacy as well as the health risks involved, since it has been proven that these risks are associated with the formation of toxic compounds, such as trihalomethanes (Allende et al., 2009; Gil et al., 2009). As a result, there is a trend to eliminate or reduce chlorine as a disinfectant in the fresh-cut industry. 
Some products have been tested as alternative disinfectants such as ozone (Selma et al., 2008; Ölmez and Akbas, 2009), UV-C (Allende and Artés, 2003; Gómez et al., 2010), organic acids (Akbas and Ölmez, 2007), chlorine dioxide (Rodgers et al., 2004) or peroxyacetic acid (Baert et al., 2009).

In recent years electrolyzed water (EW) has been considered a new eco-innovative technique showing good results as a sanitizer (Wang et al., 2006; Abadias et al., 2008). There are two types of EW with sanitizer properties, acidic electrolyzed water (AEW) and neutral electrolyzed water (NEW). These solutions are generated by electrolysis of a diluted $\mathrm{NaCl}$ solution $(0.5-1.0 \%)$. AEW has a strong bactericidal effect on most known pathogenic bacteria due to its low $\mathrm{pH}(2-4)$ and high oxidation-reduction potential (ORP $>1000 \mathrm{mV}$ ). In addition, because it contains active oxidizers like hypochlorous acid (Kim et al., 2000; Len et al., 2000), it is effective in killing food-borne pathogens under in vitro conditions and in reducing microbial counts and pathogens on vegetables. NEW has also a strong bactericidal effect when the $\mathrm{pH}$ is between 5.0-8.5 and the ORP is between 500$700 \mathrm{mV}$.

Several studies have revealed that EW is effective in reducing or eliminating pathogenic microorganisms on minimally-processed vegetables (Yang et al., 2003; Gomez-Lopez et al., 2007; Abadias et al., 2008; Koide et al., 2009). However, its efficacy on fresh-cut fruits has only been reported in the reduction of $E$. coli in fresh-cut apples (Wang et al., 2006, 2007; Nunes et al., 2010).

The aim of this work was to evaluate the efficacy of AEW and NEW on the reduction of the population of Escherichia coli O157:H7, Listeria innocua and Salmonella choleraesuis subsp. choleraesuis on fresh-cut apples.

\section{MATERIAL AND METHODS}

\section{Bacterial Cultures}

A non-toxicogenic strain of E. coli O157:H7 NCTC 12900, Listeria innocua CECT-910 and Salmonella choleraesuis subsp. choleraesuis (Smith) Weldin serotype Michigan, ATCC BAA-709 were used in this study. Listeria innocua has been used as a model organism for L. monocytogenes (Omary et al., 1993; Francis and O'Beirne, 1997). The bacterial strains were maintained on solid TSA (Tryptone Soy Agar) medium at $4 \pm 1^{\circ} \mathrm{C}$. Prior to experiments each microorganism was sub-cultured for $24 \pm 2 \mathrm{~h}$ at $37 \pm 1^{\circ} \mathrm{C}$ on TSA and then in $50 \mathrm{ml}$ of TSB (Tryptic Soy Broth) medium and incubated at $37^{\circ} \mathrm{C}$ and $150 \mathrm{rpm}$ for $24 \pm 2 \mathrm{~h}$. To recover cells, each bacterium was centrifuged at $8000 \mathrm{rpm}$ for $15 \mathrm{~min}$ and the pellet was resuspended in $50 \mathrm{ml}$ of saline peptone $(8.5 \mathrm{~g} / \mathrm{L} \mathrm{NaCl}$ and $1 \mathrm{~g} / \mathrm{L}$ peptone). Inoculums with $10^{7} \mathrm{cfu} / \mathrm{ml}$ were prepared by adjusting the suspension concentration according to an optical density standard curve $(420 \mathrm{~nm})$. Concentration of cells were confirmed by plating drops of $20 \mu \mathrm{l}$ in triplicate onto the surface of the TSA medium using Miles and Misra method (1938) and incubated at $37 \pm 1^{\circ} \mathrm{C}$ for $24 \pm 2 \mathrm{~h}$.

\section{Apple Slice Preparation}

'Royal Gala' apples used in this study were purchased in a local supermarket and stored at $0.5 \pm 0.5^{\circ} \mathrm{C}$ before processing. Apples were washed, then sanitized by immersion and rubbed in a sodium hypochlorite solution (commercial bleach) at $0.5 \%$ for $30 \mathrm{~s}$, and dried. After drying, they were aseptically cut in slices of $25 \mathrm{~g}$ each, with a sterilized stainless-steel knife. The core was removed and only the portions with the skin were used.

\section{Effect of Inoculation Time}

To determine the optimal conditions to inoculate the pathogens, a study of inoculation and drying times was made in apple plugs of $1 \mathrm{~g}(1 \mathrm{~cm}$ long and radius of $0.5 \mathrm{~cm}$ taken with a sterile cork borer). Disinfected apples were prepared, as previously described and inoculated during 1, 2 or 3 min with drying times of $0.5,1,2,3$ or $4 \mathrm{~h}$ (data not shown). As a result, the time of 3 min of agitation and 30 min of drying was chosen for the assays. 


\section{Preparation of Treatment Solutions}

AEW and NEW were generated using an EW generator (Envirolyte EL-400, Envirolyte Industries International Ltd., Estonia) following manufacturer instructions. A saturated sodium chloride solution was pumped into the equipment and the current passing through the EW generator was set at 20-23 A. AEW and NEW were collected from each outlet in flasks and stored at $4{ }^{\circ} \mathrm{C}$. Solutions of $\mathrm{AEW}$ and $\mathrm{NEW}$ at 50 and $100 \mathrm{ppm}$ of free chlorine were also prepared by diluting in distilled water immediately before treatment. Distilled water (DW) and sodium hypochlorite $(\mathrm{H})$ solution at 50 and $100 \mathrm{ppm}$ of free chlorine were used as control. Sodium hypochlorite solutions were prepared by diluting a $4 \%$ sodium hypochlorite solution (commercial bleach) with DW. All solutions were stored at $4^{\circ} \mathrm{C}$ and used within $1 \mathrm{~h}$. The properties of each solution were determined, including ORP, $\mathrm{pH}$ and free chlorine concentrations. All measurements were made immediately before treatments at $4^{\circ} \mathrm{C}$. The $\mathrm{ORP}$ and $\mathrm{pH}$ were measured with the use of a pH-meter (model GLP-21, Crison, Barcelona) using an ORP electrode (ref. 5261) and a $\mathrm{pH}$ electrode (ref. 5202) respectively. Free chlorine concentrations were determined by using a free and total chlorine photometer (model HI9133, HANNA Instruments, Woonsocket, RI, USA).

\section{Antimicrobial Activity of AEW and NEW on Fresh-Cut Apples Inoculated with E. coli, L. innocua or $S$. choleraesuis}

Apple slices were submerged in a $10^{7} \mathrm{cfu} / \mathrm{ml}$ suspension of E. coli, L. innocua or $S$. choleraesuis for 3 min with $150 \mathrm{rpm}$ orbital agitation. Inoculated samples were airdried under a laminar flow hood for $30 \mathrm{~min}$ before receiving the washing treatment. Inoculated apple slices were divided in 8 batches of 10 slices each. The time of exposure to the washing treatments was selected based on the studies carried out in our laboratory. Previously, we determined the effect of treatment exposure time ( 3 and $5 \mathrm{~min}$ ) using E. coli, and the results obtained showed that higher reductions were achieved with $5 \mathrm{~min}$ exposure time (Graça et al., 2010). Each batch was treated for 5 min at $150 \mathrm{rpm}$ agitation in flasks containing $500 \mathrm{ml}$ solution of one of the following treatment solutions: DW, H100, H50, AEW100, AEW50, NEW100 and NEW50. After treatment, apple slices were drained and rinsed twice with cold distilled water for $3 \mathrm{~min}$ at $150 \mathrm{rpm}$ and left to dry under a laminar flow hood for $30 \mathrm{~min}$. Untreated, but inoculated, samples were used as control and each treatment was done in triplicate. Once dried, apple slices from each treatment were divided in 2 batches ( 5 slices each). One was used immediately and fruits from the other batch were packed in polyethylene bags $(0.065 \mathrm{~mm}$ thick $)$ and kept at $4 \pm 0.5^{\circ} \mathrm{C}$ for 5 days. Concentration of each bacterium on apple samples was determined after drying and 5 days after cold storage. For each disinfection treatment, $25 \mathrm{~g}$ of apple slices were transferred into sterile Stomacher bags and mixed with $225 \mathrm{ml}$ of sterile saline peptone and homogenized for $2 \mathrm{~min}$ in a Stomacher as described before. Homogenates were serially diluted in saline peptone and drops of $20 \mu \mathrm{l}$ in triplicate were plated onto the surface of the TSA medium using Miles and Misra method (1938) and incubated at $37 \pm 1^{\circ} \mathrm{C}$ for $24 \mathrm{~h}$. Colonies were counted and the results expressed as cfu $\mathrm{g}^{-1}$ of apples. This experiment was repeated three times.

\section{Statistical Analysis}

Values represent the means of 3 different experiments, with 3 replicates per treatment per experiment. Data were subjected to analysis of variance and Duncan's multiple range tests using SPSS v.16.0 software (SPSS Inc., USA). Significant differences in survival population values were established by the least significant difference at the 0.05 level of significance.

\section{RESULTS AND DISCUSSION}

Inoculation and dry time did not influence the initial population of $E$. coli O157:H7 on apple slices (data not shown), and the time of $3 \mathrm{~min}$ of agitation and $30 \mathrm{~min}$ of drying was chosen for the assays. This procedure will assure an adequate and 
homogeneous contact between pathogen and fruit samples, and simulate the period between fresh-cut fruit contamination and the disinfection treatment, in case that microbial contamination occurs at some point during peeling, cutting or slicing, and sanitizing process in commercial conditions. The initial viable cells recovered after $30 \mathrm{~min}$ of inoculation for $3 \mathrm{~min}$ on unwashed apple slices were 6.35, 5.30 and $5.73 \mathrm{log}$ $\mathrm{cfu} / \mathrm{g}$ for E. coli, L. innocua and S. choleraesuis, respectively.

In fact it is necessary to establish a standardized method to determine the efficacy of sanitizers, including the selection of strains, preparation of inoculums, inoculation procedure, detection and enumeration recovery of pathogens or groups of microorganisms from fresh-cut fruit before designing experiments to calculate the efficacy of treatments with disinfectants (FDA, 2001).

Electrolyzed water and sodium hypochlorite treatments were shown to be effective for reducing $E$. coli, L. innocua and $S$. choleraesuis. The bactericidal activity of the treatments depended upon the type of sanitizer, within the same sanitizer upon the concentration of free chlorine and pathogen (Table 1).

For $E$. coli the higher bactericidal activity was observed in apple slices washed with AEW100 and AEW50, obtained reduction values of 2.47 and $2.09 \log \mathrm{cfu} / \mathrm{g}$, respectively. For concentrations of $100 \mathrm{ppm}$ of free chlorine, reductions observed with NEW and $\mathrm{H}$ were less than $2 \log$ units and no differences were observed between these two treatments. The lowest bactericidal activity was obtained with NEW50, and no differences between populations on apple slices treated with NEW50 and DW were observed.

Treatments with AEW, NEW and $\mathrm{H}$ significantly decreased the viable cells of L. innocua in apple slices. The population was reduced more than $1.20 \mathrm{log} \mathrm{cfu} / \mathrm{g}$ with AEW100 and with H100. Washing with AEW50 resulted in a reduction of $1.15 \mathrm{cfu} / \mathrm{g}$. The inactivation of $L$. innocua achieved with the other treatments was similar and lower than $1.00 \log \mathrm{cfu} / \mathrm{g}$. DW did not reduce L. innocua population. In general, the weakest bactericidal effect was observed against $L$. innocua, maybe because this species is less sensitive to chlorine than the other foodborne pathogens. In fact, Nguyen-the and Carlin (1994) suggest that inactivation of L. monocytogenes on vegetables by chlorine is limited.

The population of $S$. choleraesuis was reduced more than $1.40 \log \mathrm{cfu} / \mathrm{g}$ with AEW100 and AEW50 washing treatments. Both NEW washings reduced more than $1.2 \log \mathrm{cfu} / \mathrm{g}$. H100 was able to reduce $S$. choleraesuis population in $1.09 \log \mathrm{cfu} / \mathrm{g}$, followed by $\mathrm{H} 50$ with $0.83 \log \mathrm{cfu} / \mathrm{g}$ of reduction. DW was the treatment with the lowest reduction, $0.65 \log \mathrm{cfu} / \mathrm{g}$.

Results obtained in this study demonstrated that, in general, AEW had a stronger antimicrobial effect than NEW and H. AEW has higher ORP and lower $\mathrm{pH}$. The high ORP could cause modification on metabolic fluxes and ATP production and low $\mathrm{pH}$ may affect the outer membrane of bacterial cells and facilitate the entry of hypochlorous acid ( $\mathrm{HOCl}$ ) into microbes (McPherson, 1993). Hypochlorous acid is the main active agent of AEW and NEW (Len et al., 2000) and is the form of free available chlorine that has the highest bactericidal activity against a broad range of microorganisms. Hypochlorous acid produces hydroxyl radical $(\mathrm{OH})$ that acts on microorganisms. Therefore the higher concentration of $\mathrm{HOCl}$ present in $\mathrm{AEW}$ produces more $\mathrm{OH}$ which combined with higher ORP and lower $\mathrm{pH}$ results in more effective antimicrobial activity.

The advantages of using electrolyzed water in the fresh cut industry to disinfect fruit are a lower adverse impact on the environment and human health, since no hazard chemicals are added during processing (Huang et al., 2008). In addition it is less expensive than other sanitizing techniques, once the initial investment is made to purchase the equipment, the only expenses are water, sodium chloride and electricity (Walker et al., 2005).

\section{CONCLUSIONS}

In this study washings with electrolyzed water (EW), either acidic (AEW) or neutral (NEW), show significant reduction of populations of E. coli, L. innocua and 
S. choleraesuis on fresh-cut apple slices. AEW with $50 \mathrm{ppm}$ and NEW with $100 \mathrm{ppm}$ of free chlorine had more or comparable efficacy than chlorinated water at $100 \mathrm{ppm}$ of free chlorine. In some cases, AEW50 efficacy was similar or superior to that of NEW100 or $\mathrm{H} 100$. It would be interesting, to test the effect of EW on various combinations of foodborne pathogens, since, as suggested in some works, population size does not affect the effectiveness of treatments as well as the effect of cold storage in inoculated and disinfected fresh-cut fruits.

\section{ACKNOWLEDGEMENTS}

This work was financially supported by PTDC/AGR-ALI/64295/2006, from Fundação para a Ciência e a Tecnologia.

\section{Literature Cited}

Abadias, M., Usall, J., Oliveira, M., Alegre, I. and Viñas, I. 2008. Efficacy of neutral electrolyzed water (NEW) for reducing microbial contamination on minimallyprocessed vegetables. Int. J. Food Microbiol. 123:151-158.

Akbas, M.Y. and Olmez, H. 2007. Inactivation of Escherichia coli and Listeria monocytogenes on iceberg lettuce by dip wash treatments with organic acids. Letters Appl. Microbiol. 44:619-624.

Alegre, I., Abadias, M., Anguera, M., Oliveira, M. and Viñas, I. 2010. Factors affecting growth of foodborne pathogens on minimally processed apples. Food Microbiol. 27:70-76.

Allende, A. and Artés, F. 2003. UV-C radiation as a novel technique for keeping quality of fresh processed 'Lollo Rosso' lettuce. Food Res. Int. 36:739-746.

Allende, A., McEvoy, J., Tao, Y. and Luo, Y. 2009. Antimicrobial effect of acidified sodium chlorite, sodium chlorite, sodium hypochlorite, and citric acid on Escherichia coli $\mathrm{O} 157: \mathrm{H7}$ and natural microflora of fresh-cut cilantro. Food Control 20:230-234.

Baert, L., Vandekinderen, I., Devlieghere, F., Van Coillie, E., Debevere, J. and Uyttendaele, M. 2009. Efficacy of sodium hypochlorite and peroxyacetic acid to reduce murine norovirus 1, B40-8, Listeria monocytogenes, and Escherichia coli O157:H7 on shredded iceberg lettuce and in residual wash water. J. Food Prot. 72:1047-1054.

Beuchat, L.R. 1996. Pathogenic microorganisms associated with fresh produce. J. Food Prot. 59:204-216.

Beuchat, L.R. 1998. Surface decontamination of fruits and vegetables eaten raw: a review. WHO/FSF/FOS/98.2. Food Safety Unit. World Health Organisation. URL: http://www.who.int/foodsafety/publications/fs_management/en/surface_decon.pdf. Accessed 8 April 2010.

Burnett, S.L. and Beuchat, L.R. 2000. Human pathogens associated with raw produce and unpasteurized juices, and difficulties in decontamination. J. Ind. Microbiol. Biot. 25:281-287.

del Rosario, B.A. and Beuchat, L.R. 1995. Survival and growth of enterohemorrhagic Escherichia coli O157:H7 in cantaloupe and watermelon. J. Food Prot. 58:105-107.

FDA (Food and Drug Administration and Institute of Food Technologists). 2001. Analysis and evaluation of preventive control measures for the control and reduction/ elimination of microbial hazards on fresh and fresh-cut produce.

http://www.fda.gov/Food/ScienceResearch/ResearchAreas/SafePracticesforFoodProce sses/ucm090977.htm.

Francis, G.A. and O'Beirne, D. 1997. Effects of gas atmosphere, antimicrobial dip and temperature on the fate of Listeria innocua and Listeria monocytogenes on minimally processed lettuce. Int. J. Food Sci. Tech. 32:141-151.

Gil, M., Selma, M., López-Gálvez, F. and Allende, A. 2009. Fresh-cut product sanitation and wash water disinfection: problems and solutions. Int. J. Food Microbiol. 134:3745 . 
Gómez, P.L., Alzamora, S.M., Castro, M.A. and Salvatori, D.M. 2010. Effect of ultraviolet-C light dose on quality of cut-apple: microorganism, color and compression behaviour. J. Food Eng. 98:60-70.

Gomez-Lopez, V.M., Ragaert, P., Ryckeboer, J., Jeyachchandran, V., Debevere, J. and Devlieghere, F. 2007. Shelf-life of minimally processed cabbage treated with neutral electrolysed oxidizing water and stored under equilibrium modified atmosphere. Int. J. Food Microbiol. 117:91-98.

Graça, A., Salazar, M., Quintas, C., Manso, T. and Nunes, C. 2010. The effect of electrolyzed water as a disinfectant for fresh-cut fruit. p.216-221 In: C. Nunes (ed.), Environmentally Friendly and Safe Technologies for Quality of Fruits and Vegetables. Universidade do Algarve, Faro.

Huang, Y.-R., Hung, Y.-C., Hsu, S.-Y., Huang, Y.-W. and Hwang, D.-F. 2008. Application of electrolyzed water in food industry. Food Control 19:329-345.

Janisiewicz, W.J., Conway, W.S. and Leverentz, B. 1999. Biological control of postharvest decays of apple can prevent growth of Escherichia coli O157:H7 in apple wounds. J. Food Prot. 62:1372-1375.

Kim, C., Hung, Y.C. and Brackett, R.E. 2000. Roles of oxidation-reduction potential in electrolyzed oxidizing and chemically modified water for the inactivation of foodrelated pathogens. J. Food Prot. 63:19-24.

Koide, S., Takeda, J., Shi, J., Shono, H. and Atungulu, G. 2009. Disinfection efficacy of slightly acidic electrolyzed water on fresh cut cabbage. Food Control 20:294-297.

Len, S.V., Hung, Y.C., Erickson, M.C. and Kim, C. 2000. Ultraviolet spectrophotometric characterization and bactericidal properties of electrolyzed oxidizing water as influenced by amperage and pH. J. Food Prot. 63:1534-1537.

Leverentz, B., Conway, W.S., Alavidze, Z., Janisiewicz, W.J., Fuchs, Y., Camp, M.J., Chighladze, E. and Sulakvelidze, A. 2001. Examination of bacteriophage as a biocontrol method for Salmonella on fresh-cut fruit: a model study. J. Food Prot. 64:1116-1121.

McPherson, L.L. 1993. Understanding ORP's in disinfection process. Water Eng. Manag. 140:29-31.

Miles, A.A. and Misra, S.S. 1938. The estimation of the bactericidal power of blood. J. Hyg. 38:732-749.

Nguyen-the, C. and Carlin, F. 1994. The microbiology of minimally processed fresh fruits and vegetables. Crit. Rev. Food Sci. 34:371-401.

Nunes, C., Graça, A. and Salazar, M. 2010. Efficacy of neutral and acidic electrolyzed water for reducing microbial contamination on fresh-cut fruits. Acta Hort. 877:657662.

Oliveira, M., Usall, J., Solsona, C., Alegre, I., Viñas, I. and Abadias, M. 2010. Effects of packaging type and storage temperature on the growth of foodborne pathogens on shredded 'Romaine' lettuce. Food Microbiol. 27:375-380.

Ölmez, H. and Akbas, M.Y. 2009. Optimization of ozone treatment of fresh-cut green leaf lettuce. J. Food Eng. 90:487-494.

Ölmez, H. and Kretzschmar, U. 2009. Potential alternative disinfection methods for organic fresh-cut industry for minimizing water consumption and environmental impact. LWT - Food Sci. Technol. 42:686-693.

Omary, M.B., Testin, R.F., Barefoot, S.F. and Rusting, J.W. 1993. Packaging effects on growth of Listeria innocua in shredded cabbage. J. Food Sci. 58:623-626.

Park, C.M., Hung, Y.C., Doyle, M.P., Ezeike, G.O.I. and Kim, C. 2001. Pathogen reduction and quality of lettuce treated with electrolyzed oxidizing and acidified chlorinated water. J. Food Sci. 66:1368-1372.

Rodgers, S., Cash, J., Siddiq, M. and Ryser, E. 2004. A comparison of different chemical sanitizers for inactivating Escherichia coli $\mathrm{O} 157: \mathrm{H} 7$ and Listeria monocytogenes in solution and on apples, lettuce, strawberries, and cantaloupe. J. Food Protect. 67:721731. 
Selma, M.V., Ibáñez, A.M., Cantwell, M. and Suslow, T. 2008. Reduction by gaseous ozone of Salmonella and microbial flora associated with fresh-cut cantaloupe. Food Microbiol. 25:558-565.

Walker, S.P., Demirci, A., Graves, R., Spence, S.B. and Roberts, R.F. 2005. CIP cleaning of a pipeline milking system using electrolyzed oxidizing water. Int. J. Dairy Technol. 58:65-73.

Wang, H., Feng, H. and Luo, Y.G. 2006. Dual-phasic inactivation of Escherichia coli O157:H7 with peroxyacetic acid, acidic electrolyzed water and chlorine on cantaloupes and fresh-cut apples. J. Food Safety 26:335-347.

Wang, H., Feng, H. and Luo, Y. 2007. Control of browning and microbial growth on fresh-cut apples by sequential treatment of sanitizers and calcium ascorbate. J. Food Sci. 72:M001-M007.

Yang, H., Swem, B.L. and Li, Y. 2003. The effect of $\mathrm{pH}$ on inactivation of pathogenic bacteria on fresh-cut lettuce by dipping treatment with electrolyzed water. J. Food Sci. 68:1013-1017.

\section{Tables}

Table 1. Survival population (log cfu/g) of Escherichia coli, Listeria innocua and Salmonella choleraesuis population on inoculated fresh-cut apples washed for 5 min with different solutions, followed by two rinses for $3 \mathrm{~min}$ with distilled water. Fruit slices of $25 \mathrm{~g}$ each were inoculated by dipping in $10^{7} \mathrm{cfu} / \mathrm{ml}$ suspension of each foodborne pathogen.

\begin{tabular}{|c|c|c|c|c|c|c|c|c|}
\hline & \multicolumn{2}{|c|}{$\mathrm{AEW}^{\mathrm{a}}$} & \multicolumn{2}{|c|}{$\mathrm{NEW}^{\mathrm{b}}$} & \multicolumn{2}{|c|}{$\mathrm{H}^{\mathrm{c}}$} & \multirow{2}{*}{$\frac{\mathrm{DW}^{\mathrm{d}}}{0 \mathrm{ppm}}$} & \multirow{2}{*}{$\begin{array}{c}\text { Untreated } \\
\text { fresh-cut } \\
\text { apples }\end{array}$} \\
\hline & $100 \mathrm{ppm}^{\mathrm{e}}$ & $50 \mathrm{ppm}$ & $100 \mathrm{ppm}$ & $50 \mathrm{ppm}$ & $100 \mathrm{ppm}$ & $50 \mathrm{ppm}$ & & \\
\hline E. coli & $3.88 \mathrm{e}$ & $4.26 \mathrm{~d}$ & $4.37 \mathrm{~cd}$ & $4.90 \mathrm{~b}$ & $4.46 \mathrm{~cd}$ & $4.60 \mathrm{c}$ & $4.62 \mathrm{c}$ & $6.35 \mathrm{a}$ \\
\hline L. innocua & $4.08 \mathrm{c}$ & $4.15 \mathrm{bc}$ & $4.39 \mathrm{~b}$ & $4.42 \mathrm{~b}$ & $4.09 \mathrm{c}$ & $4.41 \mathrm{~b}$ & $5.30 \mathrm{a}$ & $5.30 \mathrm{a}$ \\
\hline S. choleraesuis & $4.32 \mathrm{e}$ & $4.22 \mathrm{e}$ & $4.51 \mathrm{de}$ & $4.48 \mathrm{de}$ & $4.64 \mathrm{~cd}$ & $4.90 \mathrm{c}$ & $5.08 \mathrm{~b}$ & $5.73 \mathrm{a}$ \\
\hline
\end{tabular}

a acidic electrolyzed water.

${ }^{\mathrm{b}}$ neutral electrolyzed water.

${ }^{\mathrm{c}}$ sodium hypochlorite.

$\mathrm{d}$ distilled water.

e ppm of free chlorine.

Rows with different letters indicate significant difference between treatments using LSD ( $<<0.05 \%)$. Values are the mean of 3 experiments with 3 replicates each and bars indicate standard deviation of means. 
